\title{
PENGEMBANGAN FASILITAS INTERPRETASI DI MUSEUM KONFERENSI ASIA-AFRIKA BANDUNG JAWA BARAT
}

\section{OLEH: Heryanti Utami}

Dosen Jurusan Pariwisata FIS UNJ

\begin{abstract}
Abstrak
Museum Konferensi Asia-Afrika (Asian-African Conference Museum) telah membangun reputasi internasional sebagai salah satu situs Pariwisata warisan dunia yang menarik, yang memperoleh sukses besar baik dalam merumuskan masalah umum dan dalam mempersiapkan pedoman operasional kerjasama antar Negara Asia Afrika serta dalam menciptakan ketertiban dan perdamaian dunia. Atraksi warisan merupakan sumber daya tak tergantikan bagi industri pariwisata sehingga penafsiran adalah komponen penting dari manajemen mereka. Situs Warisan perlu memiliki atribut unik, kuat berkarakter serta penafsiran dan penyajiannya harus mengakomodasi kebutuhan pengunjung. Studi ini meneliti bagaimana penafsiran dan pengalaman dalam konteks Pariwisata Heritage. Sebuah model yang diusulkan menggabungkan dua pendekatan yang saling melengkapi dalam analisis kepuasan: pendekatan kognitif didasarkan pada kualitas dan diskonfirmasi, pendekatan afektif didasarkan pada emosi. Analisis empiris yang dilakukan pada sampel pengunjung ke interpretasi memungkinkan kita untuk mengkonfirmasi bahwa kualitas yang dirasakan adalah penentu langsung dari kepuasan, seperti juga emosi. Akhirnya, cara di mana teknik interpretasi dipelajari, sebagai generator dari kepuasan pengunjung melalui pengalaman.
\end{abstract}

\section{Pendahuluan}

Bandung memiliki kredibillitas yang tinggi untuk Industri Pariwisata dengan sebagian besar wilayahnya dikelilingi oleh pegunungan ini memiliki potensi wisata alam yang melimpah dan beragam kebudayaan yang unik. Beberapa objek wisata yang Terkenal di Bandung seperti Tangkuban Perahu, Sari Ater, Kawah Putih, Situ Patenggang dan objek wisata lainnya. Selain wisata alam, Bandung memiliki potensi Heritage Tourism

yang luar biasa khususnya untuk bangunan-bangunan monumental berarsitektur indah berciri art deco seperti Gedung Sate, Institut Teknologi Bandung, Bangunan di sekitar Jalan Braga dan lain-lain. Saat ini, Heritage Tourism semakin tumbuh dengan pesat perkembangannya dan dinobatkan sebagai salah satu komponen yang paling signifikan di industri pariwisata ${ }^{1}$ yang ditandai

${ }^{1}$ Alzua, 1998 dan Herbert, 1995 di dalam Poria et al, 2003) 
banyaknya literatur-literatur tentang Heritage Tourism. ${ }^{2}$ Museum-museum, Taman-taman Nasional dan tempattempat bersejarah diakui telah berhasil untuk meningkatkan kunjungan wisatawan dan menjadi pilihan utama di dalam kepariwisataan di seluruh dunia (Ryan dan Dear, 1995). Heritage, atau warisan berupa berbagai peninggalan dalam segala bentuk, penting bukan hanya sebagai sebuah identitas kota/landmark (Katam, S \& Abadi,L, 2005) dan negara tapi juga bernilai ekonomi serta memberi dampak sosial (wisatakotatoea.com).

Sebagian besar museum didirikan di suatu bangunan tua yang mempunyai nilai sejarah yang signifikan yang telah di renovasi agar menunjang tujuan dari museum tersebut (Timothy \& Boyd, 2002). Hal ini juga dilakukan di Museum KAA yang menempati Gedung Merdeka yang dulunya merupakan gedung yang digunakan untuk KAA. Tujuan untuk menempatkan Museum KAA adalah untuk mengabadikan peristiwa KAA yang diselenggarakan pada tahun 1825 April 1955 yang merupakan peristiwa yang sangat bersejarah bagi politik luar negeri negara Indonesia (www.museum-indonesia.net).

Menurut Seabroke \& Miles (1993); dalam Marsongko, E.P (1996) mengatakan bahwa "Interpretasi merupakan aktivitas pendidikan yang bertujuan mengungkap arti dan pemanfaatan hubungan antar objekobjek asli di suatu tempat, melalui pengalaman langsung dan media ilustrasi, bukan sekedar

2 Balcar and Pearce, 1996; Fyall and Garrod, 1998; Hollinshead, 1988; Poria et al, 2001. mengkomunikasikan suatu hal yang sesungguhnya”. Perlu digaris bawahi bahwa fungsi dari teknik interpretasi merupakan salah satu elemen yang menjadi kekuatan pendukung penyampaian komunikasi dan pendidikan bagi pengunjung. Hal ini sejalan dengan tujuan suatu Museum yaitu melakukan usaha mengkomunikasikan, dan memamerkan benda nyata kepada masyarakat untuk kebutuhan studi, pendidikan, dan kesenangan.

Dapat disimpulkan bahwa pelayanan fasilitas interpretasi memiliki tujuan dan peranan di dalam penyediaan fasilitas yang menyenangkan dan pengalaman yang bersifat edukatif serta mengarah kepada tujuan konservasi dan berkelanjutan (Timothy \& Boyd, 2002) bagi pengunjung dan yang terpenting untuk pengelola untuk mencapai tujuan pengembangan yang telah ditetapkan melaului pemahaman pengunjung terhadaop tujuan-tujuan yang ada, sekaligus untuk meningkatkan nilai rekreasi dari kunjungan wisatawan.Berdasarkan hal diatas, maka penulis mencoba mengulas kepentingan interpretasi di Museum KAA ini dengan Tujuan untuk mendapatkan sejumlah fakta/data penelitian yang akan diteliti dan dianalisis sehingga dapat digunakan sebagai dasar/acuan untuk mengembangkan fasilitas interpretasi di Museum Asia Afrika sebagai upaya untuk meningkatakan pengalaman wisata pengunjung. Pengetahuan mengenai hal tersebut merupakan masukan berharga bagi perusahaan untuk menentukan langkah sendiri (continous self improvement) dalam 
kaitan untuk meningkatkan daya saing dengan kompetitor sejenis lainnya

Berdasarkan latar belakang dan permasalahan yang teridentifikasi tersebut diatas, dapat dikemukakan permasalahan sebagai berikut: Bagaimanakah penerapan Interpretasi di Museum Konfrensi Asia-Afrika ? Apakah persepsi dan ekspetasi pengunjung akan interpretasi sudah terpenuhi di Museum Asia-Afrika? Seberapa besar keuntungan yang diperoleh pengunjung selama berada di Museum Konfrensi Asia Afrika?

Adapun Kerangka pikir yang dikembangkan dalam penelitian ini digambarkan sebagai berikut:

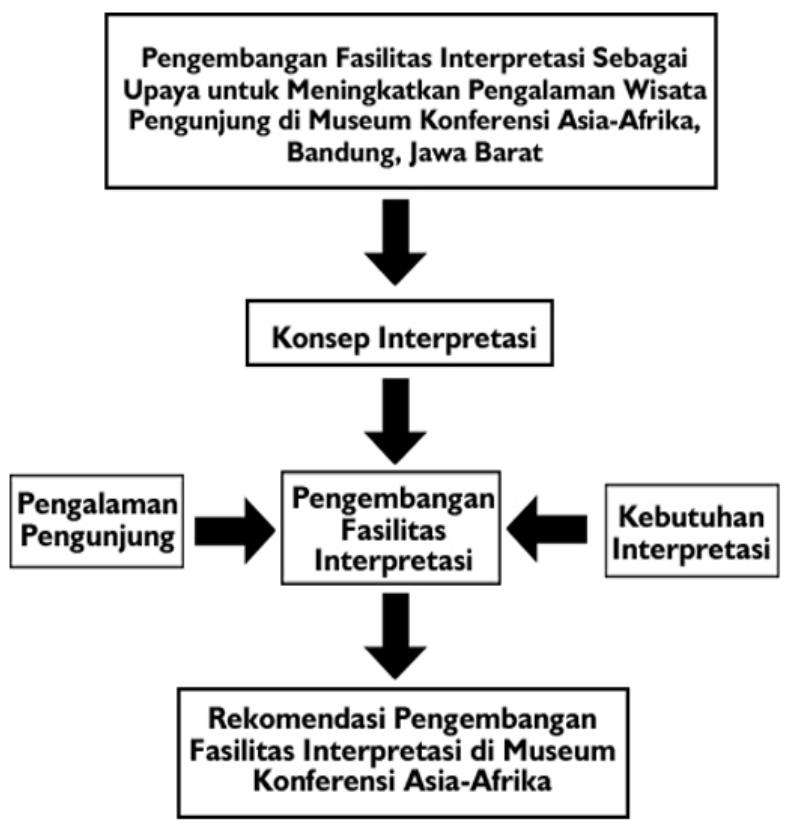

\section{Pengertian Pariwisata}

Pariwisata menurut Yoeti (1996: 112) berasal dari bahasa Sansekerta, bersinonim dengan pengertian "tour". Pendapat ini berdasarkan pemikiran sebagai berikut: kata Pariwisata terdiri dari dua suku kata yaitu masing masing kata "pari"dan "wisata". Pari, berarti banyak, berkali-kali, berputar putar, lengkap (ingat kata paripurna). Wisata, berarti perjalanan, bepergian yang dalam hal ini sinonim dengan kata "travel"dalam Bahasa Inggris. Atas dasar itu, maka kata "pariwisata" seharusnya diartikan sebagai perjalanan yang dilakukan berkali- kali atau berputar- putar dari suatu tempat lain, yang dalam Bahasa Inggris disebut dengan kata "tour", sedangkan untuk pengertian jamak, kata "kepariwisataan"dapat digunakan kata "tourisme"atau "tourism".

Batasan yang lebih bersifat teknis dikemukakan oleh Hunzieker dan Krapt. Yoeti (1996: 115) yaitu batasan pariwisata yang di berikan sebagai berikut:

"Tourism is the totally of the relationship and phenomona arising from the travel and stay of strangers (ortsfremde), provide the stay does not imply the establishment of a permanent resident".

Disini yang di maksud dengan kepariwisataan adalah keseluruhan daripada gejala-gejala yang di timbulkan oleh perjalanan dan pendiaman orang- orang asing serta penyediaan tempat tinggal sementara, asal pendiaman itu tidak tinggal menetap dan tidak memperoleh penghasilan dari aktivitas yang bersifat sementara itu. Batas yang diberikan oleh Hunzieker dan K. Krapf ini merupakan batasan yang diterima secara ofisial oleh The Association International des Experts Scietifigui du Tourism (AIEST).

\section{Konsep Heritage Tourism}

Secara literal, heritage berarti sesuatu yang diwariskan (Parks 
Canada,1994). Dalam artian yang lebih spesifik dan di dalam konteks pariwisata, Heritage Tourism merupakan salah satu bentuk dari suatu atraksi wisata yang tujuannya adalah untuk mengilustrasikan segala sesuatu yang berhubungan dengan masa lalu. 3 Hal ini didukung juga dengan pernyataan Yale, 1991 di dalam Garrod \& Fyall, 2000 bahwa "Heritage Tourism has been viewed simply as tourism centered on what we have inherited, which can mean anything from histroric buildings, to art works, to beautiful scenery”. Millar (1989) juga mengungkapkan bahwa bangunan Heritage mempunyai beberapa fungsi yaitu berfungsi sebagai atraksi wisata, identitas suatu daerah, sebagai tempat pengetahuan/pendidikan dan kadangkadang bisa juga berfungsi untuk meningkatkan ekonomi masyarakat setempat.

Banyak pertentangan yang terjadi untuk menjadikan bangunanbangunana heritage ini sebagai atraksi wisata, salah satu sebabnya adalah pengerusakan-pengerusakan yang disebabkan oleh wisatawan. 4 Walaupun banyak kritik terhadap atraksi-atraksi heritage, namun Heritage Tourism meberikan kontribusi yang sangat positif terhadap industri pariwisata yang mengarah ke konsep Pariwisata yang berkelanjutan (Hall \& McArthur, 1996).

\section{Visitor Management}

Visitor Managment adalah suatu konsep baru yang tujuannnya menyeimbangkan segala sesuatu yang

3 (Johnson \& Thomas 1995 di dalam Millar, 1999)

4 Rahman di dalam Nuryanti, 1997 terkait dengan keberlangsungan dan keberlanjutan dari suatu atraksi wisata. Dampak dari konsep Visitor Management ini adalah mengoptimalkan keuntungan-keuntungan yang di dapat oleh para wisatawan di suatu destinasi (Davidson \& Maitland, 1997). Mason (2003) memberi tiga point di dalam Visitor Management:

Mengontrol jumlah pengunjung, memodifikasi perilaku pengunjung, engadaptasi "source" (atraksi wisata) agar bisa selaras dengan kebutuhan pengunjung, agar bias meminimalisasikan dampak negatif.

Kalau di suatu destinasi dibuka untuk umum dan dijadikan sebagai atraksi wisata, kita harus memastikan kalau para pengunjung yang datang dimenej dengan baik agar tidak terjadi kapasitas yang berlebihan yang dampaknya bisa menurunkan kualitas pengalaman, sehingga harus direnacanakan dan di jaga dengan sangat baik (Cooper et al, 1993).

Ada beberapa metode yang bisa digunakan untuk mengoptimalkan pengalaman wisatawan, Metode Direct dan Metode In-direct. Metode Direct atau Hard Management berupaya secara langsung untuk tidak bertoleransi terhadap perilaku wisatawan yang negatif, sedangkan metode in-direct atau soft managment lebih berusaha untuk mengarahkan pengunjung ke suatu pilihan yang postif dengan memberikan penjelasan yang komprehensif (Peterson \& Lime, 1979).

\section{Hard Management:}

Metode ini biasanya menggunakan suatu strategi yang konkrit tanpa adanya suatu toleransi seperti 
Restriction (larangan), constraint or limitation (pembatasan) dalam segala bentuk seperti: secara fisik (penutupan suatu daerah yang dianggap membahayakan) dan secara keuangan (denda). Bila dalam suatu atraksi wisata seringkali mengalami kepadatan pengunjung, ada beberapa strategi yang bisa gunakan untuk menguranginya, seperti:

Booking secara advance, Pengunjung yang tidak mematuhi aturan diharuskan membayar denda, Memperpanjang jam buka agar mengurangi kepadatan pengunjung, Harga tiket masuk dinaikan, Melakukan zonasi : membagi beberapa daerah yang disesuaikan dengan kebutuhannya, dimana suatu daerah yang rentan bisa terjaga dengan baik. Suatu daerah biasanya berisi 4-5 zona serta jalur dan rute sirkulasi. 5

\section{Soft Management:}

Metode ini menggunakan cara-cara yang lebih lunak dibanding metode sebelumnya, metode ini mengarahkan para wisatawan agar lebih memahami kondisi suatu atraksi wisata dan menciptakan kesadaran agar mereka bisa meminimalisasikan dampakdampak negatif. Hal ini bisa dilakukan sebelum para pengunjung memasuki atraksi wisata. (Pedregal \& Diekmann, 2004). Salah satu alat dalam melakukan metode in-direct adalah interpretasi. Interpretasi adalah alat yang effective untuk menjelaskan tentang dampak-dampak negatif yang bisa di timbulkan di suatu atraksi wisata sekaligus menjelaskan bagaimana cara untuk terhindar dari

5 Swarbroke, 2002; Glasson et al; Buckey \& Pannel, 1990 dampak-dampak tersebut (Garrod et al).

Sebagian besar dari para pengunjung mempunyai pengetahuan yang terbatas atas perilaku mereka yang bisa mengarah ke suatu bentuk yang destruktif. 6 Maka dari itu, objektivitas dari Interpretasi ini bukan untuk membatasi perilaku para pengunjung tetapi untuk menciptakan pengertian untuk mereka, melalui pengertian timbul suatu penghargaan, dari penghargaan terhadap sesuatu akan mengarah kepelestarian (National Park Services, 1995)

\section{Konsep Interpretasi}

Interpretasi di definisikan sebagai bentuk proses komunikasi yang melahirkan suatu emosi dan hubungan intelektual diantara ketertarikan penonton dan penjelasan dari suatu hal yang penting dari sebuah objek. 7 Interepretasi juga bisa dimaknai sebagai aktivitas pendidikan dengan tujuan untuk menjelasakan sesuatu subjek dan objek, yang dijelaskan oleh orang yang sudah mempunyai pengalaman (tour guide) dan mediamadia yang illustratif. 8 Menurut Seabroke \& Miles (1993) interpretasi bukan hanya menjelasakan suatu informasi, tetapi mengumpulkan, memproses dan mempresentasikan secara cepat, tepat dan menarik untuk disajikan, agar para pengunjung merasa tertarik dan kemudian mempunyai keinginan yang kuat untuk menggali informasi yang belum terungkap di suatu situs, bangunan

\footnotetext{
${ }^{6}$ Manning, 1986; Lucas, 1984

7 National Asscociattion for Interpretation, 2000

8 Tilden, 1967 di dalam Seabroke \& Miles, 1993
} 
maupun artefak yang akan mengarah kepada suatu bentuk penghargaan.

Dari perpsektif konservasi, interpretasi harus memiliki tujuan untuk meningkatkan kesadaran pengunjung akan konservasi, dapat menghormati nilai-nilai kebudayaan dan berperilaku yang sesuai di suatu situs (Rivers, 1998; Eagles, 2002). Hal ini dikung dengan pernyataan dari Uzzel (1989) yang mengatakan bahwa Interpretasi adalah alat untuk menjaga kelestarian suatu bangunan bersejarah.

Prinsip interpretasi di dalam pelaksanaannya haruslah memiliki tujuan tertentu, seperti yang ditulis oleh Seabroke \& Miles, 1993, menerangkan tujuan interpretasi, yaitu: To provide an enjoyable and rewarding educational experience for visitor, To enhance visitor appreciation and understanding of the site, To maximise the carrying capacity of the site and minimize the impact of visitors, To promote an undersatnding of the agency providing or operating the site.

\section{Personal Interepretation:}

Veverka (1994) mengatakan bahwa "The Fundamental elemet of verbal communication is to consider the words we use or how we say to them, they may convey hidden messages as well”. Hal ini dimaksudkan agar kita harus mengetahui karakteristik dari para pengunjung, agar kita bisa memilahmilah informasi yang kita sajikan untuk berbagai tipe pengunjung. Personal interpretation atau yang lebih di kenal dengan sebutan tour guide lebih bisa membuat pengunjung merasa nyaman dan membuat komunikasi dua arah yang akan memulai suatu diskusi yang menarik. Walau bagaimana pun, semuanya tergantung kepada kemampuan dan bakat masing-masing individu untuk berkomunikasi secara interactif dan menarik (Sharpe, 1982).

\section{Non personal Interpretation:}

Non personal interpretation mengkomunikasikan informasi kepada pengunjung menggunakan suatu alat/media yang tujuannya untuk membantu memfasilitasi interpreter/tour guide di luar kemampuannya dan kehadiran non personal interepretaion ini bukan untuk menggantikan keberadaan interpretter/tour guide tetapi melengkapi dan menyempurnakan informasi yang akan disampaikan kepada pengunjung (Sharpe, 1982). Media-media yang digunakan antara lain: Audio visual devices, Written Material:Brosur \& Leaflet, Exhibits, Visitor Centres

Dapat disimpulkan bahwa pelayanan fasilitas interpretasi memiliki tujuan dan peranan di dalam penyediaan fasilitas yang menyenangkan dan pengalaman yang bersifat edukatif bagi pengunjung dan yang penting bagi pengelola untuk mencapai tujuan pengembangan yang telah ditetapkan melalui pemahaman pengunjung terhadap tujuan-tujuan yang ada, sekaligus meningkatkan nilai rekreasi dari kunjungan para wisataan.

\section{Konsep Experiential Marketing}

Experience atau pengalaman merupakan sesuatu yang dicari oleh manusia dalam hidupnya. Sebuah pengalaman menjadi suatu tolak ukur 
keberhasilan atau kegagalan seseorang dalam menjalani suatu peristiwa tertentu dalam hidupnya dan merupakan sebuah akhir dari proses yang didapatkan seseorang ketika berinteraksi baik secara langsung maupun tidak langsung terhadap suatu tempat, lingkungan atau terhadap sesama manusia. Dalam hal ini pengalamanan wisata atau pengalaman berwisata merupakan pengalaman yang didapat pengunjung atau wisatawan pada saat melakukan kunjungan ke suatu kawasan wisata atau objek wisata dan pengalaman yang didapat pada saat mereka berinteraksi dengan pengelola, masyarakat setempat sampai pengelola kawasan wisata tersebut.

Pengalaman beriwisata yang berkesan akan memberikan "rasa" tertentu dalam benak wisatawan, sehingga dapat memunculkan loyalitas wisatawan yang akan menyebabkan terjadinya kunjungan berulang. Hal ini diperkuat oleh pernyataan Bernd $\mathrm{H}$. Schmitt dalam bukunya Experiential Marketing (1999:60) bahwa "They often result from direct observation and/or participation in eventswhether they are real, dreamlike, or virtual".

Pada dasarnya, Experiential Marketing memiliki dua aspek, yaitu Strategic Experiential Models (SEMs) yang terdiri atas beberapa tahapan terciptanya pengalaman dan Experience Providers (ExPros) yang merupakan alat bantu yang untuk mewujudkan experiential marketing tersebut. Schmitt juga menjelaskan mengenai tipe-tipe yang menjadi tahapan (SEMs) dalam terciptanya suatu pengalaman yaitu: Sense ;
Merupakan sensasi yang dapat dirasakan pancaindera manusia. Seperti pada penglihatan, contoh: interior dan eksterior yang unik, warna yang menarik, pada pendengaran, contoh: alunan musik, pada penciuman, contoh: aromatheraphy, pada pengecap / lidah, contoh: rasa asam, manis, perabaan pada kulit, contoh: kasar, lembut, Feel ;Merupakan perasaan dan emosi positif dan negatif yang timbul pada saat mengkonsumsi produk atau berada di suatu tempat. Mood dan emotion dimana yang pertama (mood) masih bersifat ringan dan mempengaruhi sebagian diri manusia, sedangkan yang kedua (emotion) sudah menjadi berat dan dapat mempengaruhi keseluruhan jiwa dan pikiran manusia, Think; Pada langkah yang ketiga ini merupakan pikiran atau ide yang muncul dari benak konsumen apabila melihat atau membaca atau mendengar sebuah merek. Contohnya muncul persepsi atas dua buah merek handphone yang berbeda (Nokia dan Siemens), dimana pengunjung secara otomatis memilih dan memilah berdasarkan kualitas, fitur dan benefit serta kemudahankemudahan yang didapat, Act ; Menyangkut tindakan fisik dan interaksi yang muncul yang disebabkan karena pengaruh luar dan opini dalam. Sebagai contoh, seseorang yang pergi ke museum akan membaca interpretasi yang ada akan lebih punya pengalaman yang memorable dibandingkan seseorang yang hanya melihat-lihat ruang pamer. Apabila pengunjung tersebut turut terlibat dan mencoba alat peraga yang ada, maka ia akan lebih memiliki 
experience yang berbeda dibandingkan dengan orang yang hanya menbaca interpretasi saja, Relate ; Relate merupakan upaya menghubungkan produk/merek dengan dirinya, orang lain atau budaya melalui suatu lingkungan sosial tertentu. Contoh, pencinta sejarah akan bersama-sama terlibat dalam Komunitas Historia Indonesia yang akan melakukan berbagai hal bersama dalam upaya melestarikan sejarah bangsa dan mengenakan atribut tertentu yang menandakan diri seseorang merupakan bagian dari komunitas tersebut, Experience ; yang akan dirasakan oleh para pengunjung pada saat mengonsumsi sebuah produk atau mengunjungi kawasan harus dirangsang berdasarkan unsur-unsur pengalaman (sense, feel, think, act, relate) diatas. Unsur-unsur pengalaman tersebut dapat disampaikan melalui berbagai pengemasan aktivitas yang ditawarkan, media informasi, cara pemberian pelayanan oleh pengelola dan pelayan di kawasan wisata dan penyampaian kualitas produk yang optimal.

Seperti telah dijelaskan diatas bahwa SEMs harus pula dilengkapi dengan ExPros dimana pengalaman bagi wisatawan tersebut dapat dibentuk oleh beberapa faktor. Dibawah ini terdapat gambar yang menggambarkan faktor-faktor yang dapat membentuk suatu experience.

\section{GAMBAR Key Experiential Providers}

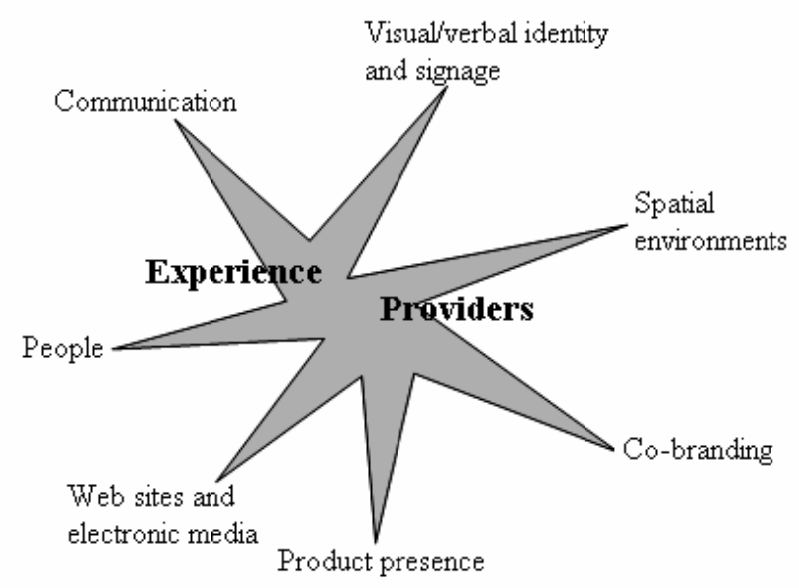

Sumber : Bernd H. Schmitt, Experiential Marketing (1999: 73)

Melalui gambar diatas, dapat dilihat bahwa bentuk komunikasi, signage, lingkungan, co-branding, tampilan produk, media elektronik dan manusia (interaksi antar manusia) yang terlibat merupakan unsur-unsur yang dapat memberikan pengalaman kepada wisatawan. Masing-masing unsur tersebut perlu direncanakan secara matang untuk memberikan sisi experience yang maksimal kepada pengunjung suatu kawasan wisata. Setiap unsur memiliki peranan yang sangat penting dalam menentukan image kawasan yang akan disampaikan oleh kawasan tersebut.

Wisata urban heritage termasuk dalam ketegori atraksi wisata buatan manusia, dimana terus menerus berkembang dan mengalami kemajuan sesuai dengan perkembangan zaman. Suatu kota merupakan bentuk dan konsep yang dirancang oleh pemerintah dan saat ini kota dapat ditawarkan oleh pemerintah sebagai salah satu objek wisata perkotaan dan 
sejarah suatu daerah. Sebuah kota diharapkan mampu menciptakan pengalaman yang unik bagi pengunjungnya, karena juga memiliki unsur cultural dan social attraction yang kuat.

\section{Metode Penelitian}

Metode yang akan digunakan dalam penelitian ini adalah metode penelitian deskriptif, yaitu "penelitian yang berusaha mendeskripsikan atau menggambarkan atau melukiskan fenomena atau hubungan antarfenomena yang diteliti dengan sistematis, faktual dan akurat" (Kusmayadi dan Sugiarto, 2000 : 29).

Dalam penelitian ini, metode deskriptif digunakan untuk menggambarkan kondisi daya tarik, amenitas, aksesibilitas, aktivitas dan juga kondisi kebijakan yang terkait serta persepsi pengalaman wisatawan. Gambaran atau identifikasi yang didapat akan dijabarkan secara sistematis, faktual dan akurat.

\section{Teknik Pengumpulan Data}

Adapun jenis data akan dicari penulis adalah data primer dan data sekunder, sedangkan teknik pengumpulan data yang akan digunakan adalah sebagai berikut :

Observasi ; Observasi dilakukan untuk mendapatkan data mengenai kondisi yang bersifat kualitatif mengenai daya tarik produk, amenitas, aksesibilitas dan ragam aktivitas di Kawasan Museum KAA . Alat kumpul data yang akan digunakan dalam observasi ini adalah daftar periksa (checklist), Wawancara ; Wawancara akan dilakukan terhadap pihak Museum KAA.
Penyebaran Kuesioner

Penyebaran kuesioner dilakukan secara langsung kepada pengunjung Museum KAA untuk memenuhi kebutuhan data primer dan mendapatkan langsung gambaran mengenai tanggapan dan kepuasan pengunjung serta pengalaman yang mereka dapatkan selama melakukan aktifitas di Museum KAA.

\section{Studi Kepustakaan}

Studi ini akan ditujukan pada data-data produk wisata dan juga kebijakan yang diterapkan yaitu berupa rencana-rencana pengembangan tata ruang kawasan dan Draft Masterplan kawasan. Data ini kemudian akan disesuaikan dengan rencana pengembangan wisata urban heritage di Kawasan Museum KAA Jakarta.

\section{Metode Penarikan Sampel}

Sampel merupakan wisatawan yang berkunjung ke Museum KAA Jakarta. Populasi dan sampel yang dianggap mewakili untuk diteliti dan kemudian ditarik kesimpulannya. Populasi yang diambil pada penelitian ini adalah para pengunjung yang berada di dalam Museum KAA. Populasi ini dinamis sehingga tidak ada sampling frame, maka dengan demikian teknik yang digunakan pada penelitian ini yaitu sample secara kebetulan (accidental sampling). Berdasarkan populasi tersebut akan diambil sample yang nantinya akan dipelajari dan dianalisa untuk ditinjau profil dan karakteristiknya yang dianggap dapat mewakili populasi. Teknik pengumpulan data yang dipilih adalah sampling nonprobabilitas dan 
peneliti tidak menggunakan prosedur pemilihan peluang. Kemudian untuk teknik nonprobability sampling ini yang digunakan adalah judgemental sampling, dimana pemilihan populasi ini berdasarkan penilaian pihak peneliti dengan mempertimbangkan kredibilitas sampel dan kebutuhan penelitian dengan menggunakan data bulan yang sama dengan pengambilan sampel pada tahun sebelumnya sebagai tolak ukur jumlah wisatawanMuseum KAA. Kemudian sampel tersebut akan dihitung dengan menggunakan rumus Slovin untuk mendapatkan jumlah representatif.

\section{Metode Pengolahan Data}

Metode pengolahan data dalam penelitian ini yaitu dengan cara mengukur variabel penelitian dengan menggunakan instrujmen pengukuran skala Likert, yang menghasilkan skala pengukuran ordinal kemudian dirubah dengan menggunakan metode succesive interval, sehingga diperoleh data dengan skala pengukuran interval.

\section{Metode Analisis Data}

Metode analisis yang digunakan untuk penelitian ini adalah disesuaikan dengan permasalahan penelitian. Untuk menguji jenis data frekuensi berdasarkan kecenderungan jawaban yang diberikan oleh responden digunakan analisis deskriptif kuantitatif. Data-data tersebut disajikan dalam bentuk tabulasi untuk memudahkan menyusun kesimpulan. Proses perhitungan statistik sederhana diperlukan dalam rangka membantu menyusun kesimpulan berdasar standard-standard yang akan digunakan.

\section{Analisa Permasalahan}

Setiap tahun, Museum KAA selalu bertambah jumlah pengunjungnya. Dibawah ini adalah table jumlah pengunjung sejak tahun 2006:

TABEL 1

JUMAH PENGUNJUNG MUSEUM KAA 2006 - JUNI 2010

\begin{tabular}{|c|c|}
\hline TAHUN & $\begin{array}{c}\text { JUMLAH } \\
\text { PENGUNJUNG }\end{array}$ \\
\hline 2006 & 87692 \\
\hline 2007 & 108732 \\
\hline 2008 & 109971 \\
\hline 2009 & 113956 \\
\hline 2019 & 103571 \\
(hingga \\
bulan \\
Juni)
\end{tabular}

Sumber: Dirjen Informasi dan Diplomasi Publik Kemlu, 2010

Dari tabel diatas, dapat dilihat jelas bahwa jumlah pengunjung Museum KAA meningkat dari tahun ke tahun. Hal ini disebabkan oleh semakin baiknya pelayanan interpretasi personal dan non personal yang dimiliki museum ini. Pengunjung Museum KAA ini terdiri dari beberapa segmen pasar, dibawah ini adalah tabel jumlah pengunjung berasal dari segmen pasar berbeda untuk tahun 2010. 
TABEL 2

DATA PENGUNJUNG MUSEUM

KAA JANUARI - JUNI 2010

\begin{tabular}{|l|c|c|c|c|c|c|c|}
\hline \multicolumn{1}{|c|}{ Pengunjung } & Jan & Feb & Mar & Apr & Mei & Jun & Jumlah \\
\hline TK/KB & 71 & 26 & - & 45 & 20 & 44 & 206 \\
SD/MI & 739 & 1269 & 3817 & 1968 & 2920 & 2247 & 12960 \\
SMP/MTs & 5761 & 8063 & 5841 & 11544 & 5510 & 10759 & 47478 \\
SMA/SMK/MA & 1909 & 2552 & 1831 & 3705 & 3389 & 3868 & 17254 \\
\hline PERG.TINGGI & 200 & 519 & 252 & 104 & 313 & 383 & 1771 \\
\hline PENELITI & 6 & 5 & 31 & 11 & 6 & 23 & 82 \\
\hline WARTAWAN & 1 & - & 32 & 40 & - & 5 & 78 \\
\hline ORGANISASI / INSTANSI & 34 & 80 & 64 & 86 & 137 & 77 & 478 \\
ASING & & & & & & & \\
\hline ORGANISASI/INSTANSIU & 900 & 410 & 703 & 4189 & 246 & 761 & 7209 \\
NON ASING & & & & & & & \\
WISNUS & 2803 & 1192 & 1491 & 3940 & 2156 & 2121 & 13703 \\
WISMAN & 328 & 256 & 349 & 424 & 382 & 567 & 2306 \\
\hline TAMU NEGARA & - & 19 & - & 5 & - & 22 & 46 \\
\hline JUMLAH ORANG & 12752 & 14391 & 14411 & 26061 & 15079 & 20877 & 103571 \\
\hline
\end{tabular}

Dari tabel diatas, tampak bahwa hingga saat ini, segmen pasar Museum KAA yang terbanyak adalah dari pelajar SMP/MTs, yang memang ditugaskan oleh sekolah untuk mengulas mengenai sejarah KAA dan sejarah Museum KAA itu sendiri. Hal ini menggambarkan bahwa museum sebagai objek wisata belum menjadi daya tarik bagi sebagian besar masyarakat. Museum hanya dijadikan sebagai objek pusat data dalam suatu kegiatan ilmiah saja, padahal museum apabila dijadikan sebagai objek wisata, maka masyarakat dengan sendirinya akan merasa terhibur sekaligus menambah wawasan mereka.

Museum, berdasarkan definisi yang diberikan International Council of Museums, adalah

"Sebuah institusi permanen, nirlaba, melayani kebutuhan publik, dengan sifat terbuka, dengan cara melakukan usaha pengoleksian, mengkonservasi, meriset, mengkomunikasikan, dan memamerkan benda nyata kepada masyarakat untuk kebutuhan studi, pendidikan, dan kesenangan. Karena itu museum dapat menjadi bahan studi oleh kalangan akademis, dokumentasi dan pemikiran imajinatif di masa depan"

Museum merupakan suatu badan yang mempunyai tugas dan kegiatan untuk memamerkan dan menerbitkan hasil-hasil penelitian dan pengetahuan tentang benda-benda yang penting bagi Kebudayaan dan llmu Pengetahuan.

Dari data diatas, maka nampak jelas bahwa museum pada dasarnya adalah sebuah objek wisata, sehingga selain sebagai pusat sumber data dan keilmuan serta budaya dan seni, maka seharusnya museum juga memiliki sisi "menghibur" untuk dapat memenuhi pengalaman berlibur wisatawan. Hal inilah yang masih belum dimiliki oleh beberapa museum di Indonesia, termasuk Museum KAA. Unsur menghibur dalam hal ini adalah sesuatu yang dapat memberikan pengalaman menyenangkan namun tetap mengusung unsur edukatif yang tinggi. Pengalaman belajar yang disertai dengan kegiatan yang menyenangkan akan sangat besar dampaknya bagi perkembangan keilmuan di Indonesia.

\section{Analisis Program layanan} Interpretasi Museum KAA Tour/ Pemanduan Keliling:

Kegiatan ini dilakukan oleh para guide/ interpreter/ pemandu kepada peserta atau wisatawan yang mengunjungi Museum KAA. Dalam hal ini, pengunjung mengikuti tour dan menerima informasi tentang bangunan Museum KAA yang bersejarah ataupun sejarah terkait dengan metode berkeliling sesuai dengan rute yang telah ditentukan. 
Umumnya sebelum dilakukan tour, peserta yang telah terdaftar dibagi kedalam beberapa kelompok dan dalam satu kelompok didampingi oleh $1-2$ orang guide/ pemandu. Jumlah peserta dalam satu kelompok biasanya berjumlah $10-15$ orang (jumlah fleksibel berdasarkan banyaknya peserta yang mengikuti program). Pihak Museum KAA seringkali membatasi jumlah peserta dalam suatu program yang akan dilaksanakan untuk meminimalisasi terjadinya penumpukan peserta pada suatu titik bangunan bersejarah dan menyebabkan terganggunya kegiatan tour antar kelompok.

Tour di Museum KAA sebenarnya memiliki nilai pengalaman yang cukup tinggi. Pengunjung dapat dengan seksama berkeliling gedung Museum KAA yang desain interior dan eksteriornya bernuansa khas kolonial Belanda. Selain itu, furniture serta hiasan serta lukisan-lukisan atau foto yang terdapat didalamnya menambah saratnya nilai museum KAA secara keseluruhan.

Dalam tour museum, guide dapat dengan mudah menyesuaikan narasi yang akan disampaikan dengan pengunjung yang mengikuti tour, baik secara demografis, geografis dan psikologis secara fleksibel dan akrab, tidak seperti pada non personal interpretation yang hanya mengacu pada penjelasan konkrit saja.

\section{Pemutaran Film Dokumenter atau Slide:}

Kegiatan pemutaran film dokumenter atau slide ini biasanya dilakukan di dalam ruangan yang disediakan oleh pihak Museum KAA.
Ruangan ini cukup besar dan dapat menampung sekitar 50 orang. Dilengkapi dengan pemutar film yang cukup baik, televisi dan layar slide di kanan kiri serta kualitas suara yang cukup jelas. Tujuan dari adanya pemutaran film dokumenter atau slide ini adalah agar pengunjung dapat lebih memahami sejarah KAA. Ruangan ini menjadi sarana untuk penanyangan film-film dokumenter mengenai kondisi dunia hingga tahun 1950-an, Konfrensi Asia Afrika dan konfrensikonfrensi lanjutannya, serta film-film documenter mengenai kondisi sosial, politik dan budaya dari Negara-negara Asia Afrika tersebut.

Salah satu aspek penting yang masih belum ada dalam kaitannya dengan pemutaran di ruangan audio visual adalah tidak terjadwalnya film yang akan diputar.Selain itu film yang diputar tidak didukung dengan teks multi bahasa.

\section{Media Promosi dan Pendistribusian Brosur:}

Museum KAA saat ini telah memiliki website : www.asianafricanmuseum. org. Website tersebut bercerita tentang sejarah dan awal mula berdirinya Museum KAA. Dalam website tersebut juga terdapat foto dan gambar-gambar gedung museum dan gambaran pada saat konfrensi tersebut berlangsung.

Brosur merupakan salah satu teknik interpretasi yang digunakan dalam memberikan informasi secara singkat dan jelas serta informatif tentang suatu objek, tempat, peristiwa ataupun lainnya yang bentuknya bervariasi. Pembagian brosur Museum KAA masih kurang efektif, karena kurangnya koordinasi antara pengelola 
Museum KAA dengan kantor dinas terkait, seperti Dinas Pariwisata, Dinas Pendidikan, Dinas Kebudayaan setempat yang seharusnya dapat berkoordinasi untuk mengahsilkan media cetak yang berkualitas dan terdistribusi dengan baik didalam dan luar kota. Bila memungkinkan untuk bekerjasama dengan pihak luar negeri, maka brosur ini juga menjadi salah satu media cetak yang sangat penting perannya hanya saja penggunaan bahasa harus disesuaikan dengan market negara yang akan dituju.

\section{Penyajian atau Tata Letak dalam Ruang Pamer:}

Gambar, foto dan peta merupakan salah satu teknik interpretasi yang digunakan dalam memberikan informasi, gambaran atau kondisi sebenarnya pada masa lampau mengenai bangunan bersejarah maupun benda- benda yang memiliki sejarah lainnya. Selain itu, penambahan fasilitas computer interaktif dalam ruang pamer juga sangat membantu pengunjung dalam mendapatkan informasi tentang sejarah Museum KAA atau sejarah KAA.

Tata letak dalam ruang pamer pada dasarnya telah memenuhi syarat dan ketentuan internasional, demikian pula dengan furnitur-furnitur pendukungnya yang seluruhnya telah modern dan disesuaikan dengan kondisi museum tanpa merusak sisi sejarahnya, namun, untuk eksterior museum, nampaknya pihak pengelola belum memaksimalkannya. Dari luar, Museum KAA ini hanya memiliki signboard besar bertuliskan "MUSEUM KONFRENSI ASIA
AFRIKA" berserta alamatnya, namun sama sekali tidak menarik perhatian pengunjung. Apalagi pintu museum ini selalu dalam keadaan tertutup dan tidak tampak ada petugas sama sekali di luar gedung. Hal ini, menyebabkan keengganan wisatawan untuk berkunjung ke Museum KAA tersebut. Museum ini kelihatan selalu sedang tutup dan tidak tampak ada kegiatan didalamnya. Seringkali wisatawan berbalik arah kembali karena tidak yakin bahwa museum ini buka.

Padahal, nampak jelas tertera pada papan penunjuk jam operasional museum secara rinci. Seharusnya, pintu masuk museum dilengkapi dengan pintu lapis kedua yang terbuat dari kaca tembus pandang, sehingga Nampak aktivitas di dalam museum tersebut.

\section{Petugas Museum KAA:}

Petugas museum KAA, dalam hal ini adalah petugas yang "Guest Contact" masih belum memiliki jiwa "hospitality" yang kental, nampak bahwa petugas yang bertugas di sudut informasi hanyalah siswa magang yang sama sekali tidak memahami museum ini secara keseluruhan. Selain itu, mereka tidak menggunakan atribut guest service officer yang sesuai seperti seragam dan nama dada. Hal ini mencerminkan ketidak professionalan Museum KAA dalam memberikan pelayanan kepada wisatawan.

Pemandu atau guide merupakan petugas yang paling penting yang dimiliki oleh sebuah museum. Pada museum ini, pemandu memiliki pengetahuan yang cukup detil dan dapat menyampaikan dengan baik dan 
jelas kepada pengunjung. Mereka juga dapat dengan seksama menjelaskan dan menggambarkan momen-momen penting Konfrensi AA. Hal ini merupakan daya tarik luar biasa bagi pengunjung. Pemandu-pemandu ini merupakan pegawai Kementerian Luar Negeri yang sudah dapat menguasai dua bahasa.

\section{Papan Penunjuk Arah:}

Papan penunjuk arah merupakan hal yang sangat penting untuk dimiliki di sebuah museum. Papan ini menunjukkan kepada pengunjung tentang letak atau keberadaan sebuah ruangan atau penunjuk titik awal perjalanan di museum tersebut hingga titik akhir, agar mendapatkan informasi secara runut dan utuh.

Di museum KAA ini, papan penjunjuk sebenarnya telah adda, namun penempatan dan bentuk papan penunjuk tersebut tidak proposional, baik secara bentuk dan ukuran, sehingga pengunjung tidak dapat melihat dengan jelas papan tersebut. Seharusnya, papan tersebut dibuat sesuai dengan tema museum secara keseluruhan, misalnya dengan menggunakan papan dan tulisan bergaya art deco dan dibuat agak besar, sehingga pengunjung dapat dengan jelas melihat tulisan tersebut, meskipun berada agak jauh dari tempat tersebut.

\section{ANALISA EXPROS DAN EXPERIENTIAL MARKETING MUSEUM KAA}

\begin{tabular}{|c|c|c|c|c|c|}
\hline ExPros & Types & sense & feel think & act & relate \\
\hline $\begin{array}{l}\text { Visual/verbal } \\
\text { signage }\end{array}$ & $\begin{array}{l}\text { Signage, audio visual, } \\
\text { komputer interaktif }\end{array}$ & $\mathrm{v}$ & $\begin{array}{ll}\mathrm{V} & \mathrm{V}\end{array}$ & $\mathrm{v}$ & \\
\hline Communication & $\begin{array}{l}\text { Teknik memandu, teknik } \\
\text { penyampainan informasi }\end{array}$ & & $\mathrm{v}$ & & $\mathrm{v}$ \\
\hline People & $\begin{array}{l}\text { Ofticers knowledge \& } \\
\text { attitudes, uniform }\end{array}$ & $\mathrm{v}$ & $\mathrm{v}$ & & $\mathrm{v}$ \\
\hline Website & www.asianafricanmuseum org & & $\mathrm{v}$ & & \\
\hline $\begin{array}{l}\text { Product } \\
\text { presence }\end{array}$ & $\begin{array}{l}\text { Diorama, kelengkapan } \\
\text { koleksi, tata letak }\end{array}$ & $\mathrm{v}$ & $\mathrm{v}$ & & \\
\hline \multirow[t]{2}{*}{ Co branding } & Kerjasama promosi dan & & & $\mathrm{v}$ & $\mathrm{V}$ \\
\hline & $\begin{array}{l}\text { pengembangan dengan pinak } \\
\text { lain. }\end{array}$ & & & & \\
\hline $\begin{array}{l}\text { Spatial } \\
\text { environment }\end{array}$ & $\begin{array}{l}\text { Otentisitas bangunan dan } \\
\text { koleksi }\end{array}$ & $\mathrm{v}$ & $\mathrm{v}$ & & $\mathrm{v}$ \\
\hline
\end{tabular}

Sumber : Olahan Penulis, 2010

Data pada tabel diatas menunjukkan bahwa masingmasing ExPros pada sarana interpretasi yang kemudian dilihat dari SEM's sebenarnya dapat meningkatkan kualitas pengalaman pengunjung. Apabila materi interpretasi baik personal maupun non personal di kembangkan dengan baik, maka kualitas pengalaman pengunjung dapat muncul secara lebih optimal.

\section{Analisis Fasilitas Interpretasi dan Pengalaman Pengunjung Museum KAA}

Berdasarkan tabel diatas, nampak dengan jelas bahwa rata-rata jawaban kuesioner sense berjumlah 2,98 yang artinya masih terbatas pada predikat cukup. Dalam hal ini maka interpretasi yang dapat membangkitkan pengalaman sense (yang berkaitan dengan panca indera) pada dasarnya masih cukup rendah. Seharusnya pihak museum dapat membangkitkan sense penglihatan pengunjung melalui papan penunjuk yang diberi tulisan sesuai dengan tema 
art deco dan diberi warna-warna yang menarik. Demikian pula dengan sense pendengaran pengunjung yang dapat dimunculkan dengan pemasangan musik-musik yang sesuai dengan tema museum pula. Selain itu, pihak Museum harus memberikan seragam kepada para pegawai, terutama yang bertugas di kantor depan museum agar pengunjung benar-benar dapat melihat dan merasakan suasana yang berbeda saat memasuki museum. Seragam menciptakan suasana yang tertib dan teratur, sehingga dapat meningkatkan pengalaman pengunjung.

Dari tabel Feel, dapat dilihat bahwa jumlahnya masih 2.67, yang artinya adalah masih kurang dari cukup. Berarti Museum KAA sebenarnya kurang dapat membangkitkan emosi pengunjung. Pengunjung kurang dapat merasakan emosi yang terbentuk baik dari suasana museum maupun dari pemandu. Sebenarnya pemandu merupakan sosok yang paling dapat mempengaruhi emosi pengunjung, namun sayangnya, pemandu tidak dapat menguasai emosi seluruh anggota tour selain karena tidak semua pengunjung menggunakan jasa pemandu, juga tidak semua serius mendengar penjelasan pemandu terutama apabila anggota tour adalah pelajar. Suasana museum sebenarnya sudah dapat membangkitkan emosi pengunjung, dilihat dari arsitektur dan interior bangunan. Namun sayangnya suasana tersebut berkesan temaram, apalagi bagian belakang museum menuju Gedung Merdeka yang gelap dan dingin. Akhirnya, suasana yang timbul adalah suasana yang senyap dan sedikit menakutkan. Untuk ruang depan museum, memang sudah terang benderang, namun feel untuk merasa nyaman dengan suasana museum masih belum terbentuk akibat terlalu sepi apabila tidak ada tour dari kelompok-kelompok tertentu.

Dari table think, dapat dilihat bahwa jumlah 2.42 masih jauh dari angka baik. Hal ini disebabkan oleh belum maksimalnya Museum KAA dalam memaksimalkan fungsinya sebagai sumber dan sarana penambah ilmu bagi masyarakat. Misalnya saja, pihak pengelola jarang sekali mengadakan event atau acar-acara yang melibatkan masyarakat. Dalam hal ini, seharusnya Museum KAA dapat mengadakan suatu acara yang berkaitan dengan sejarah, misalnya Hari Pahlawan atau mengenang KAA yang dimeriahkan dengan kuis-kuis dan sebagainya.

Sedangkan dari tabel Act dapat dilihat bahwa nilai 3 berarti ada dalam posisi cukup baik. Memang secara tidak langsung, keberadaan komputer interaktif di ruang pamer memang telah merangsang pengunjung untuk menggunakannya. Pengunjung menjadi lebih antusias dalam mendengar dan melihat secara langsung apa yang terdapat dalam komputer tersebut. Selain itu ketersediaan ruangan audio visual juga dapat memunculkan pengalaman pengunjung untuk aktif dalam menerima pengetahuan melalui filmfilm yang ditayangkan.

Dari tabel Relate dapat dilihat bahwa nilai 2.98 berarti ada dalam posisi cukup baik. Memang secara tidak langsung, keberadaan komputer interaktif di ruang pamer memang 
telah merangsang pengunjung untuk menggunakannya. Pengunjung menjadi lebih antusias dalam mendengar dan melihat secara langsung apa yang terdapat dalam komputer tersebut. Selain itu ketersediaan ruangan audio visual juga dapat memunculkan pengalaman pengunjung untuk aktif dalam menerima pengetahuan melalui film-film yang ditayangkan.

\section{Kesimpulan dan Saran}

Berdasarkan pada data aktual yang diperoleh melalui penyebaran kuesioner dan analisis mengenai halhal tersebut. Maka kesimpulan berdasarkan Faktor-faktor pembentuk experience (pengalaman), adalah sebagai berikut : Sarana interpretasi yang ada di Museum KAA harus dapat merangsang munculnya pengalaman pengunjung yang muncul dari panca indera manusia (sense). Untuk museum, maka panca indera yang dimaksud adalah yaitu penglihatan, pendengaran, penciuman, peraba, diamana meliputi suasana dan dekorasi ruangan, pemasangan papan penunjuk arah yang indah, alunan musik yang sesuai dengan tema, pemasangan alat pewangi ruangan otomatis untuk menghilangkan bau apek dan pengap serta komputer atau media Touch screen yang dapat diakses pengunjung dengan mudah. Sampai saat ini, unsur sense yang ada di Museum KAA masih belum cukup mempengaruhi pengalaman pengunjung.

Sarana interpretasi yang ada di Museum KAA hingga saat ini juga masih belum terlalu kuat mempengaruhi pengalaman feel pengunjung KAA. Dalam hal ini semestinya Museum KAA dapat membangkitkan emosi pengunjung melalui musik, pencahayaan, atmosfir serta peran serta pemandu yang dapat memberikan keterangan serta penjelasan dengan cara yang dapat mempengaruhi perasaan dan emosi pengunjung, misalnya melalui intonasi suara, ekspresi wajah dan gerak tubuh yang sedemikian rupa.

Sarana interpretasi yang ada sedikit banyak telah dapat menambah pengalaman pengunjung dari sisi ilmu pengetahuan (think). Namun, nampaknya masih belum banyak pengunjung yang merasa bahwa sarana interpretasi yang ada dapat menambah pengetahuan mereka. Hal ini dapat dilihat dari tabel hasil kuesioner yang diisi pengunjung masih berada pada kisaran 2.42 yang berarti "cukup". Bararti, masyarakat atau pengunjung sebenarnya berharap bahwa Museum KAA dapat menambah sarana interpretasinya atau dapat menciptakan alat interpretasi baru yang lebih canggih, menarik dan sarat akan informasi yang dibutuhkan pengunjung. Selama ini, komputer interaktif yang ada hanya terbatas pada informasi seputar KAA dan peristiwa yang menyertainya, tidak dilengkapi dengan peta museum atau rincian mengenai benda-benda koleksi yang ada secara rinci.

Untuk pengalaman act sampai saat ini nampaknya masih belum dapat merangsang pengunjung untuk aktif melakukan sesuatu. Pihak Museum nampaknya masih belum dapat membuat atau merencanakan suatu kegiatan yang dapat melibatkan pengunjung secara aktif dalam kegiatan yang menambah 
pengetahuan mereka, sedangkan untuk sarana interpretasi yang mengarah pada relate dalam hal ini harus dapat melibatkan masyarakat dalam hal ini misalnya mengkomunikasikan suatu kegiatan atau suatu gerakkan yang fungsinya untuk menambah pengetahuan dan melestarikan museum.

\section{Saran}

Adapun rekomendasi yang dapat diberikan kepada pihak pengelola Museum KAA adalah sebagai berikut: Menjadikan Museum KAA sebagai Social-Recreational Reasons bagi masyarakat. Dalam hal ini bagaimana menciptakan museum sebagai objek wisata dan hiburan selain tetap menjaga fungsi utamanya sebagai pusat informasi dan sumber data mengenai sejarah KAA dan segala hal yang berkaitan dengan pelaksanaannya tersebut. Selain itu harus juga menjadikan Museum KAA sebagai Educational Reasons, dimana menjadikan museum ini sebagai pusat belajar sejarah yang nyaman dan menyenangkan bagi semua kalangan.

Sementara itu, mengadakan kerjasama dengan pihak luar untuk mengadakan pengembangan sarana interpretasi yang interaktif dan modern perlu dijajaki, misalnya dengan diorama yang dapat bergerak dan bersuara sesuai dengan tomboltombol yang dipilih pengunjung. Diorama ini akan sangat menarik untuk diakses siapapun dan dari kalangan manapun. Kerjasa lainnya yaitu mengadakan kerjasama untuk membuat suatu acara yang sarat akan kegiatan yang menyenangkan sekaligus memperkenalkan museum dan menambah pengetahuan masyarakat akan KAA.

Untuk menambah daya tarik interior museum, merubah papanpapan penunjuk arah agar di beri tulisan bergaya art deco dan diberi warna yang lebih atraktif. Selain itu, hendaknya ruang pamer yang ada diperluas tidak hanya terpusat pada satu ruangan saja, adapun ruangan lainnya harus diberi komputer interaktif dan diorama yang menggambarkan suasana pada saat itu, misalnya pada ruangan konfrensi, harus ada diorama yang menggambarkan saat konfrensi berlangsung disertai pencahayaan serta musik-musik yang sesuai untuk membangkitkan pengalaman pegunjung.

\section{Daftar Pustaka}

Davidson, R and Maitland, R.

(1997)Tourism Destinations. Bath:

Bath Press

Garrod, B and Fyall, A. (2000) Managing Heritage Tourism:Annals of Tourism Research, 27 (3), p.682-708.

Gunn, C.A., (1979) Tourism Planning, Crane Russak: New York

Hall, C.M and McArthur, S. (1996) Heritage Management in New Zealand and Australia: Visitor Managment, Interpretation and Marketing. Auckland: Oxford University Press

Hall, C.M and McArthur, S. (1998) Integrated Heritage Management. London: The Stationary Office.

Herbert, D.T. (1989b) Does Interpretation Help? Aldesshot: Avebury

Inskeep, E (1991) Tourism Planning: An Integrated and Sustainable Development, New York, Van Nostrand Reinhold 
Jubenville, A (1976) Outdoor Recreation Planning,London, W.B Saunders Company

Katam, S and Abadi,L, (2005) Album Bandoeng Tempo Doeloe. Bandung: NavPress Indonesia

Kusmayadi and Sugiarto,E (2000) Metodologi Penelitian Dalam Bidang Kepariwisataan,Jakarta, PT Gramedia Pustaka Utama

Mason, P. (I2003) Tourism Impacts, Planning and Management. London: Butterworth-Heinemann.

Medlik, S (1991) Managing Tourism, Oxford: Butterworth-Heinemann

Millar, S (1989) Heritage Management fot Heritage Tourism. Tourism Management, 10 (1), p9-14

Nuryanti, W (1996) Tourism and Culture: Global Civilization in Change? Yogyakarta: Gadjah Mada University

Page, S.J (2003) Tourism Management: Managing for Change. Oxford: Butterworth-Heinemann

Poria, Y., Reichel, A and Brian, A (2003)Motivations and Expectations. Annals of Tourism Research,33 (1), p 162-178

Poria, Y., Butler, R and Airey, D. (2006) The core of Heritage Tourism: Annals of Tourism Research, 30(1),p. 238-254.

Schmitt, Bernd H, 1999, Customer Experience Management, New York: The Free Press

Schmitt, Bernd H, 1999, Experience Marketing, New York: The Free Press

Seabroke, W and Miles, C.W.N (1993)

Recreation Land

Management.London, E \&FN SPON

Shackley, M. (1998) Visitor

Management:Case Studies from

World Heritage Sites. Oxford:

Butterworth-Heinemann.

Sharpe, G (1982) Interpreting The

Environment. Chichester: Wiley

Sugiyono, 2004. Metode Penelitian Bisnis, Bandung: Alfabeta
Swarbrooke, J (2002) The Development and Management of Visitor Attractions. 2nd ed. Oxford: Butterworth-Heinemann

Tilden, F. (1978) Interpreting Our Heritage.North Carolina: The University of North Carolina Press

Timothy D.J and Boyd, S.W (2003) Heritage Tourism. Essex. Pearson Education Limited.

Uzzel, D and Ballantyne, R. (1998)Contemporary Issues in Heritage and Environmental Interpretation. London: The Stationary Office

Veverka, J.A (1998) Interpretive Master Planning: The Essential Planning Guide for Interpretive. Tustin: Acorn Naturalist

Yoeti O.A (1996). Pengantar Ilmu Pariwisata. Bandung : Penerbit Angkasa. 